by Alain Blieck ${ }^{1}$, Susan Turner ${ }^{2,3}$, Carole J. Burrow ${ }^{3}$, Hans-Peter Schultze ${ }^{4}$, Carl B. Rexroad ${ }^{5}$, Pierre Bultynck ${ }^{6}$ and Godfrey S. Nowlan ${ }^{7}$

\title{
Fossils, histology, and phylogeny: Why conodonts are not vertebrates
}

\author{
${ }^{1}$ Université Lille 1: Sciences de la Terre, FRE 3298 du CNRS «Géosystèmes», F-59655 Villeneuve d'Ascq cedex, France. \\ E-mail: Alain.Blieck@univ-lille1.fr \\ ${ }^{2}$ Monash University, Geosciences, Box 28E, Victoria 3800, Australia \\ ${ }^{3}$ Queensland Museum, Geosciences, 122 Gerler Road, Hendra, Queensland 4011, Australia \\ ${ }^{4}$ Kansas University, Biodiversity Institute \& Natural History Museum, 1345 Jayhawk Blvd., Lawrence, KS 66045-7593, USA \\ ${ }^{5}$ Indiana Geological Survey, 611 North Walnut Grove, Bloomington, IN 47405-2208, USA \\ ${ }^{6}$ Institut Royal des Sciences Naturelles de Belgique, Département de Paléontologie, Rue Vautier, 29, B-1000 Bruxelles, Belgium \\ ${ }^{7}$ Geological Survey of Canada, $3303-33^{\text {rd }}$ Street NW, Calgary, AB T2L 2A7, Canada
}

The term vertebrate is generally viewed by systematists in two contexts, either as Craniata (myxinoids or hagfishes + vertebrates s.s., i.e. basically, animals possessing a stiff backbone) or as Vertebrata (lampreys + other vertebrae-bearing animals, which we propose to call here Euvertebrata). Craniates are characterized by a skull; vertebrates by vertebrae (arcualia); euvertebrates are vertebrates with hard phosphatised tissues in the skeleton. The earliest known possible craniate is Myllokunmingia (syn. Haikouichthys) from the Lower Cambrian of Chengjiang, south China. Euvertebrates appear in the Ordovician. C. H. Pander is sometimes thought to have been the first to propose that conodonts are vertebrates, but he did have doubts about the fish affinities of conodonts. This proposal was revived in the 30s and especially in the 80 s of the $20^{\text {th }}$ century and given elevated status in 2000 through a cladistic analysis based upon interpretation of conodont mineralized tissues as homologous to those of vertebrates. This analysis resolved conodonts within the clade Vertebrata s.s., and incorporated a 'Total Group Concept' (TGC), including conodonts in the TG Gnathostomes (= jawed vertebrates). This resulted in the unusual scenario in which "teeth" appear before jaws. We reject the TGC nomenclature as applied to early vertebrates. In addition, based on all existing evidence, we consider that conodont hard tissues and several other anatomical structures in conodonts are not homologous with those of vertebrates. Making a revised cladistic analysis, eliminating characters unknown in fossils, conodonts appear stemward (i.e. more basal) to craniates and are thus interpreted as basal chordates at best. To help resolve the phylogenetic relationships of conodonts and chordates, the analysis should be extended to include non-chordate taxa.

\section{Historical background}

A recent paper by Sweet and Cooper (2008), within the classic paper series of Episodes, drew our attention and prompted this response. Their paper concerned the discovery and the concept of conodonts by Christian Heinrich Pander (1856). He was the first scientist to describe conodonts, which are phosphatic microfossils originally found in the Ordovician-Lower Carboniferous of the East Baltic area (see Sweet and Cooper, 2008). In his seminal paper, Pander (1856, p. 5) gave the first diagnosis of conodonts: "Kleine glänzende, längliche, nach oben oder gegen das eine Ende spitz verlaufende, nach unten sich allmälig oder plötzlich erweiternde, bald mehr bald weniger gekrümmte, meist mit scharfen Rändern (Kielen), einem vorderen und einem hinteren, versehene, den Fischzähnen an Gestalt sehr ähnliche Überreste.", that is "Tiny, lustrous, elongated remains very similar in shape [our emphasis] to fish teeth, [which] extend upward or toward one end into a point; [which] widen gradually or abruptly downward; [which are] more or less curved, and most [of which] have sharp margins (keels), one in front and one in back." (Sweet and Cooper, 2008, p. 434). However, the assertion of Sweet and Cooper (2008, p. 434) that "Conodonts, the subjects of the first part of Pander's 1856 monograph, were exclusively considered to be the teeth of an extinct group of fishes" has to be questioned. Although the title of Pander's (1856) publication starts with "Monographie der fossilen Fische ..." several paragraphs in his monograph indicate that he did have doubts about the fish affinities of conodonts. He wrote:

- "We continue now with the structure of these teeth, which deviates from all what has been considered as significant ichthyological character until now" (Pander, 1856, p. 6; HPS' and ST's translation);

- "Nothing [hardly anything] valid can be quoted against the similarity of the external gestalt with teeth of extinct and still living fish genera; one could only raise objections against their 
internal structure which is completely different from that [structure] what has been accepted in fishes until now." (ibid., p. 8-9);

- "We could not find any indication in any publication on microscopy, which could cause us to compare the internal structure of the Silurian teeth [= the conodonts] with that of extinct or living fishes." (ibid., p. 9);

- "The complete unawareness of animals from which the Silurian teeth originated, and the lack of similar extinct and still living animals, which could serve for comparison, places great difficulties for a systematic classification." (ibid., p. 18).

The hypothesis that conodonts were fish teeth was not widely supported until the end of the $20^{\text {th }}$ century, and subsequently a plethora of hypotheses has since been published on the phylogenetic relationships of conodonts. The function and biological affinities of their phosphatic elements have been hotly debated for more than 100 years. This is in spite of their empirical usefulness for solving geological problems especially in biostratigraphy, extensively used in the $20^{\text {th }}$ century (e.g. Branson and Mehl, 1933; Sweet and Bergström, 1971). Various authors have suggested affinities including everything from plants, annelid jaws or fish, and for their function everything from gill rakers to copulatory spicules to teeth. Scott (1934, p. 448) used an examination of assemblages of conodont elements on shale surfaces to conclude that "They are more like, in fact are almost identical to, the jaw apparatus of annelid worm jaws", and (ibid., p. 455) "The many points which have been enumerated [including a pivotal one of the absence of a pulp cavity in conodonts, see Turner et al., 2010] make it practically impossible for them to be considered as fish." [Note that certain advanced carnivorous teleosts have no pulp cavity either, a feature which may be interpreted as 'secondary'.] In the same year, Schmidt (1934) published natural assemblages of Pennsylvanian conodont elements and compared them with gill arch elements of fishes. Gross (1954, 1957, 1960), opposing Schmidt (1934), attempted to demonstrate how different the conodont tissues are from tissues of fishes. Hass (1962) summarized the views attributing conodonts to various groups of animals: molluscs (mostly gastropods), annelids or other worms, arthropods (trilobites or crustaceans), chordates (fish or "primitive fishlike animals"), or unclassified animals. Müller's (1981) paper has a very complete list of the papers classifying the various conodont affinities including plants, coelenterates, aschelminthes, gnathostomulids, molluscs, annelids, arthropods, tentaculates, chaetognaths, and chordates. Among the hypotheses attributing conodonts to "invertebrates", we must also mention a more recent, but heterodox one: Tillier and Cuif (1986) proposed that conodonts were aplacophoran molluscs (also Tillier and Janvier, 1986), an hypothesis immediately dismissed by Briggs et al. (1987), but supported by Janvier (1988) who then changed his mind (e.g. Janvier, 1995, and later). Schultze (1996), Kemp and Nicoll (1996), Kemp (2002 a-b), Turner et al. (2004) and Reif (2006) came out strongly against the vertebrate nature of conodonts based principally on histology and morphogenetic (meaning the style of growth) evidence.

The hypothesis that conodonts were vertebrates, was rejuvenated by Schmidt $(1934,1950)$ and Schmidt in Schmidt \& Müller (1964) and, since the discovery of nearly complete animals and the reinterpretation of conodont hard tissues as homologous to vertebrate tissues (Sansom et al., 1992, and later papers), this idea was supported by a group of palaeontologists centered around Richard Aldridge and his students at the University of Leicester (Turner et al., 2010).

The first computer-based parsimony analysis of conodont phylogenetic relationships was made by Janvier (1996) who obtained 79 shortest trees with the HENNIG86 software (that is, 79 most parsimonious solutions of distribution of characters for establishing the affinities of conodonts with vertebrate groups). Conodonts were resolved as sister-group to lampreys (see Aldridge and Briggs, 2009, p. 84) in only one of the trees; in most others, their presence in the data matrix of the analysis in fact introduced "noise" that appeared as what is called "henningian combs" for the consensus trees (i.e. mostly unresolved cladograms; see Janvier, 1996, fig. 5). Later, Philip Donoghue decided to re-make a phylogenetic analysis of conodonts after a question he posed to one of us (A.B.) during the conodont symposium held in Bologna (Italy) in 1998 (Donoghue et al., 2000). It is in the latter paper that Donoghue et al. (2000) resurrected the hypothesis that conodonts are vertebrates, placing them between cyclostomes (myxinoids and lampreys) and other vertebrates. He and collaborators even developed the idea through the Total Group Concept of Jefferies (1979) that the so-called Total Group including "Recent jawed vertebrates + basal jawed vertebrates + basal agnathan taxa + conodonts" had to be called "Total Group Gnathostomes" (TGG), supposedly all vertebrates with jaws. However, their TGG includes all gnathostomes and "agnathans" (= vertebrates without jaws) as well as conodonts (without jaws) (see, e.g., Donoghue et al., 2000; Donoghue and Aldridge, 2001). These results were mainly based upon data from partially body-preserved specimens of conodonts attributed to Clydagnathus windsorensis from the Granton Shrimp Bed, Lower Carboniferous, Scotland (Briggs et al., 1983), and Promissum pulchrum from the Soom Shale, Upper Ordovician, South Africa (Gabbott et al., 1995). [Note that the conodont mineralized elements are usually the only preserved conodont parts in Cambrian to Triassic sediments; so, the latter occurrences of body elements may be considered as exceptional for the fossil record].

This TGG is both a nonsensical name and concept because one has to take in consideration that: (1) contrary to Donoghue et al.'s (2000) opinion, the mineralized tissues of conodonts are not the same as those in vertebrates, (2) conodonts have no jaws, (3) their "teeth" are not homologous to vertebrate teeth from a phylogenetic point of view, and (4) from a functional point of view the morphology of most dentiform elements in a conodont apparatus is not adapted to function as teeth, vertebrate or otherwise (Turner et al., 2010). We decided to write a review paper on this question explaining our position (Turner et al., 2010), because this "conovert" hypothesis has been introduced as uncontested 'fact' in most recent Englishlanguage books, textbooks and handbooks for students, and because the authors neglect to cite any hypotheses that oppose or challenge their own.

In fact, although palaeohistological studies of conodonts have been conducted for a long time (e.g. Hass, 1941; Gross, 1954, 1957, 1960; Schmidt and Müller, 1964; Müller and Nogami, 1971), homology of their mineralized tissues to those of vertebrates was established by Donoghue and his co-authors only after the conodontbearing animal was interpreted as a vertebrate. In fact, homologizing conodont elements with vertebrate teeth was not possible only using histology (see the paper of Sansom et al., 1992, which is at the start of the story), in the absence of independent anatomical arguments, a reason why the controversy has lasted so long. 

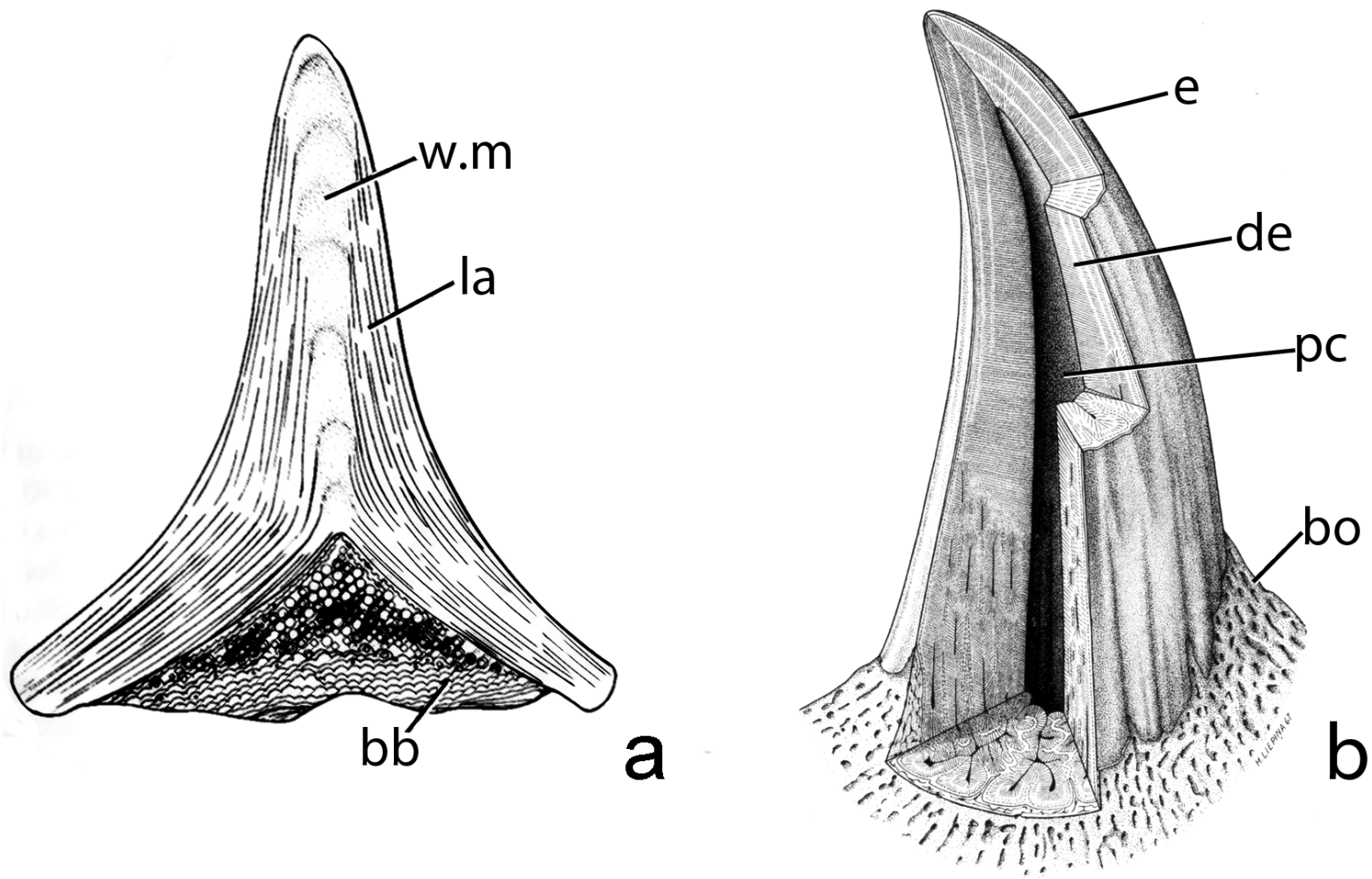

Figure 1. Comparison of cross section of an euconodont element (a) with an osteichthyan (sarcopterygian) tooth with pulp cavity (b) from Schultze (1969, fig. 1: 'polyplocodont' tooth of Panderichthys) [Only hard tissues are shown]. Abbreviations: bb, basal body; bo, (attachment) bone; de, dentine; e, enamel; la, lamellar tissue; pc, pulp cavity; w.m, albid tissue or white matter. Not to scale.

Another point that needs discussion is the way conodonts and vertebrates are treated in classical books on microfossils such as that of Armstrong and Brasier (2005). They wrote that "Conodonts (or euconodonts) were a group of primitive jawless vertebrates, which ranged from the Upper Cambrian to the uppermost Triassic. They were the first vertebrates to produce a mineralized skeleton and are primarily known from scattered elements of their feeding apparatus." (op. cit., p. 249). So: (1) why are microremains of vertebrates (scales, denticles, teeth) not included in such books on microfossils which traditionally are only concerned with "invertebrates"; and (2) why are conodonts still considered as "invertebrates" by being included in such books? May we hypothesize that this is at least partly due to the reciprocal ignorance of palaeontologists regarding the fossils of which they are not specialists? Palaeovertebrate experts are most often palaeo-anatomists and do not work with such microfossils as conodonts, and conodont experts are most often biostratigraphers and are not involved in palaeo-anatomical and phylogenetic topics. Despite this lack of knowledge, a disturbing but now well established trend has arisen (e.g., noted by King et al., 2009) to include conodonts as a subphylum Conodontophorida (= conodont-bearing animals) inside the phylum Chordata.

\section{Where is the problem?}

Here we will speak only of the euconodonts sensu, e.g., Janvier (1997), that exclude protoconodonts and paraconodonts. The phylogenetic relationships of the latter are unclear. Only euconodonts are known from a number of partially articulated specimens where the conodont elements are preserved in what is interpreted as the anterior end (mouth) of the conodont animal (Briggs et al., 1983; Gabbott et al., 1995; and refs. in Turner et al., 2010). From our point of view, the problem with interpretation of conodonts as vertebrates resides in three main points:

- the interpretation of features of conodont elements as homologous to vertebrate teeth (Donoghue et al., 2000, and later papers);

- the specific application of the concept of Total Group to early vertebrates (e.g., Donoghue et al., 2000; Donoghue and Aldridge, 2001);

- and the choice of the outgroups in Donoghue et al.'s (2000) analysis.

Concerning conodont characters, we have summarised our results as follows (Turner et al., 2010, commented and completed):

1. Cephalisation is low in conodonts, possibly at the level of extant cephalochordates, whereas it is much higher in craniates where cephalisation reaches an advanced state of development;

2. Conodonts lack segmentally-arranged paraxial elements, a feature of vertebrates;

3. Conodont trunk musculature is simple V-shaped as opposed to a $\mathrm{W}$-shape in craniates [where a few exceptions are known as, e.g., in lungfish where trunk musculature is arranged as simple V-shapes (Bemis, 1987), and in larval teleosts (ref. in Pridmore et al., 1997)];

4. Conodonts lack dermal elements in median fins, whereas median fins of vertebrates possess dermal fin rays that are articulated at the base with supporting cartilaginous elements;

5. Conodonts lack a gill basket, a basal feature of chordates; in a recent paper Sansom et al. (2010) demonstrated that the gill basket 
in the amphioxus (Branchiostoma) and larval lamprey (Lampetra) is a very decay resistant structure and preserved even when other structures are gone; so, it should be present in conodont animals if they had it;

6. Conodonts lack a dermal skeleton including bony plates whereas all vertebrates have odontodes with bone of attachment and a unique pulp system (Figure 1);

7. Conodont element ultrastructure, revealed by TEM and SEM (Kemp, 2002a; Trotter and Eggins, 2006; Trotter et al., 2007), has a crystalline structure very different in crystal size and arrangement than that of vertebrates: the albid material of conodonts is formed by extraordinarily large crystals in contrast to the fine small crystals of bone, dentine and enamel in vertebrates (Figure 1);

8. Conodont hyaline material shows a histochemical reaction for collagen, which is not present in vertebrate enamel (Kemp, 2002b);

9. Conodont element albid material (white matter) does not react for collagen, which is a major element in vertebrate bone (ibid.);

10. The lacunae in the albid material are too small for eukaryote cells such as osteocytes;

11. In general, the morphogenesis of conodont elements differs from that of vertebrates (Figure 2).

12. Additionally, we do not accept the interpretation of conodont

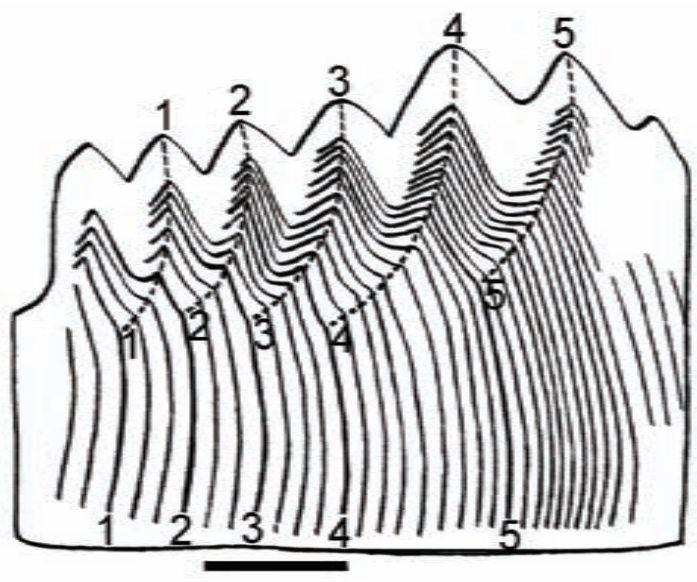

eyes as homologous to vertebrate ones; we could even argue that conodonts probably had no eyes because eyes need a brain, a feature which has not been demonstrated in conodont animals (but this should be carefully checked all through "invertebrates" as well).

The second point is concerned with the Total Group Concept (TGC) as applied to early vertebrate phylogeny (e.g., Jefferies, 1979; Donoghue et al., 2000; Donoghue and Aldridge, 2001). The terminology which is used in the TGC distinguishes between "crown group" (CG), "stem group" (SG) and "total group" (TG). A CG is the smallest monophyletic group, or clade, to contain the last common ancestor of all extant members, and all of that ancestor's descendants; all organisms that are more closely related to this CG than to any other living group are referable to its SG (a SG is only composed of fossil members). A CG plus its SG considered together constitute the TG (Figure 3). We disagree with the use of the same name for the "total group" as for the "crown group" (e.g., gnathostomes, tetrapods, etc.). In the case of gnathostomes (traditionally used for vertebrates with jaws), Donoghue et al. (2000; also Donoghue and Aldridge, 2001) decided that the Total Group including "Recent jawed vertebrates + basal jawed vertebrates + basal agnathan taxa + conodonts" (= all vertebrates, excluding cyclostomes, + conodonts) had to be called "Total Group Gnathostomes" that is Total Group of
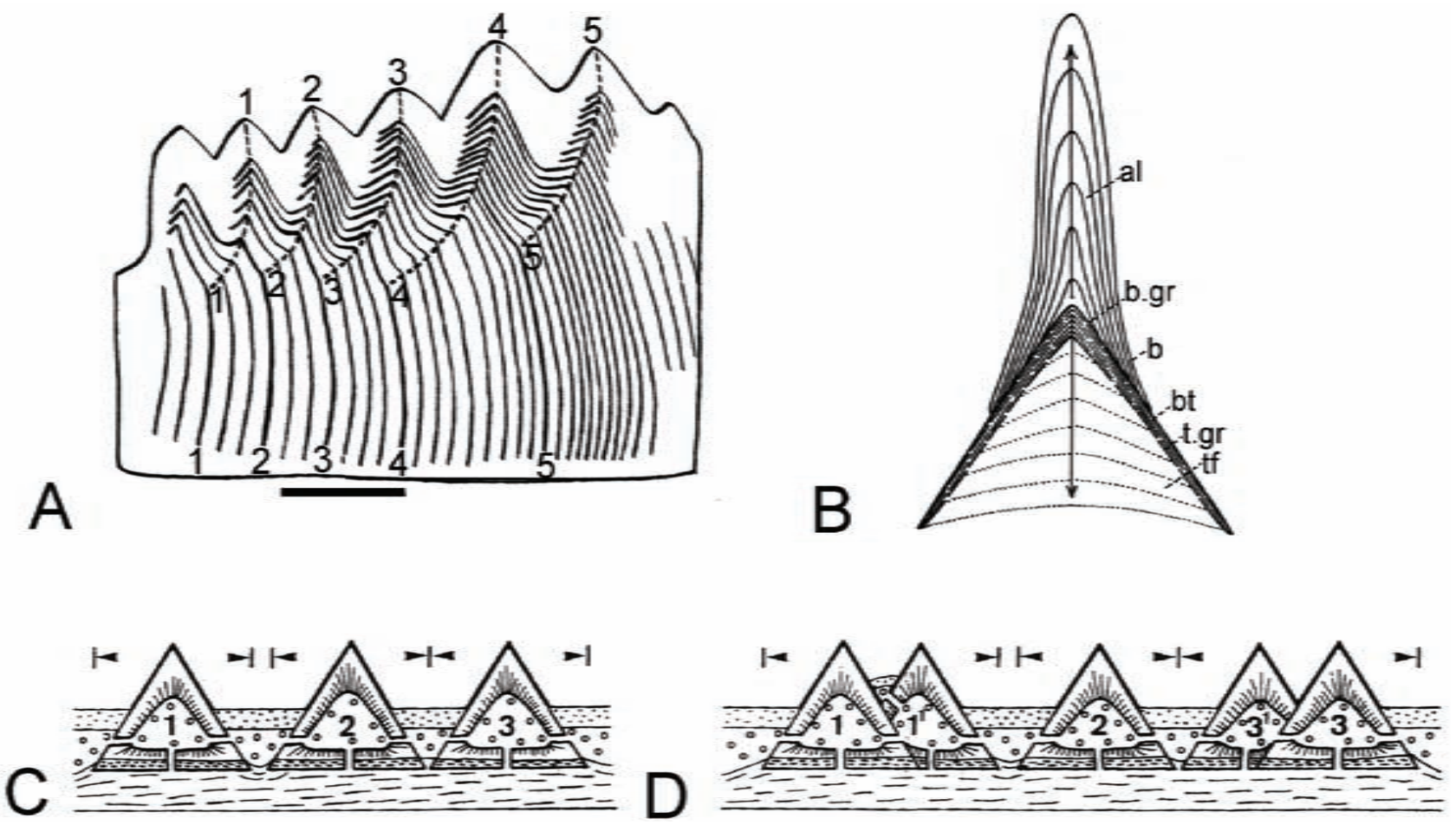

Figure 2. Histology of conodont element (showing continuous growth) vs. vertebrate scale or tooth (odontode) formed in a papilla of mesenchymous cells: A - drawing of longitudinal section showing continuous growth with lateral additions and formation of serration of the conodont Gnathodus texanus modified from Gross (1954, fig. 2: 1-5, subsequent addition of serrations) contra Donoghue (1998) Type 4 growth (reproduced in Reif 2006: fig. 4) where a basal body [or is it white matter?] apparently occurs in each serration [reproduced with permission from Senckenbergiana lethaea]; $\boldsymbol{B}$ - schematic cross section to show continuous growth (arrows) of conodont element and basal filling (after Gross 1957, fig. 4: al, lamellar tissue; b, basis; b.gr, basal groove; bt, basis cone; tf, inner basal filling, t.gr, boundary between the two kind of filling of the basal grove); $C$-D - formation of vertebrate odontodes in comparison to conodont growth in A. The odontode is formed by a papillary organ (with enamel organ, odontoblasts and osteoblasts in a single morphogenetic step). It cannot grow, but is enlarged instead by addition of a new odontode, that is formed by a new papillary organ resulting from a new interaction between ectoderm and mesenchyme (modified from Reif 2006, fig. 3a): thick line, enamel or enameloid; radiating lines, dentine with pulp cavity underneath; basal tissue, attachment bone = cement with thin lines of deposition). Note the presence of pulp in vertebrate. 


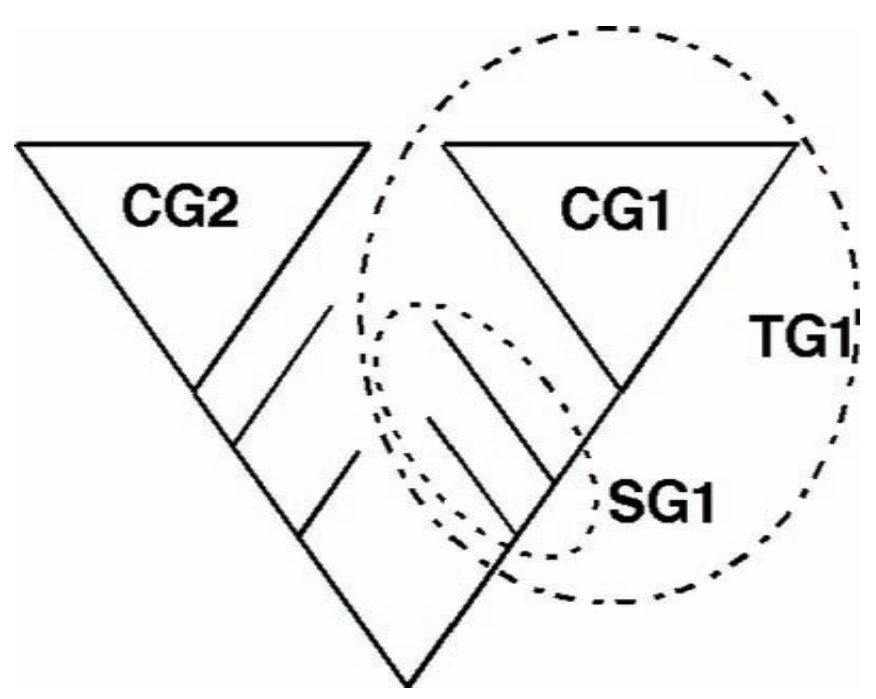

Figure 3. Schematic illustration of crown groups (CG1 and CG2), stem group (SG1) and total group (TG1). CG1 and CG2 are two sister groups of living organisms (including eventually some fossils).

vertebrates with jaws (see, e.g., Donoghue and Purnell, 2005, fig. 1). So, their TG Gnathostomata includes forms that definitely lack jaws, i.e., the basal fossil agnathans (ostracoderms) and even the conodonts that they consider as vertebrates. In other words, for instance, the jawless ossified fishes known as ostracoderms in the Old Red Sandstones (cephalaspids, pteraspids, thelodonts, anaspids and many

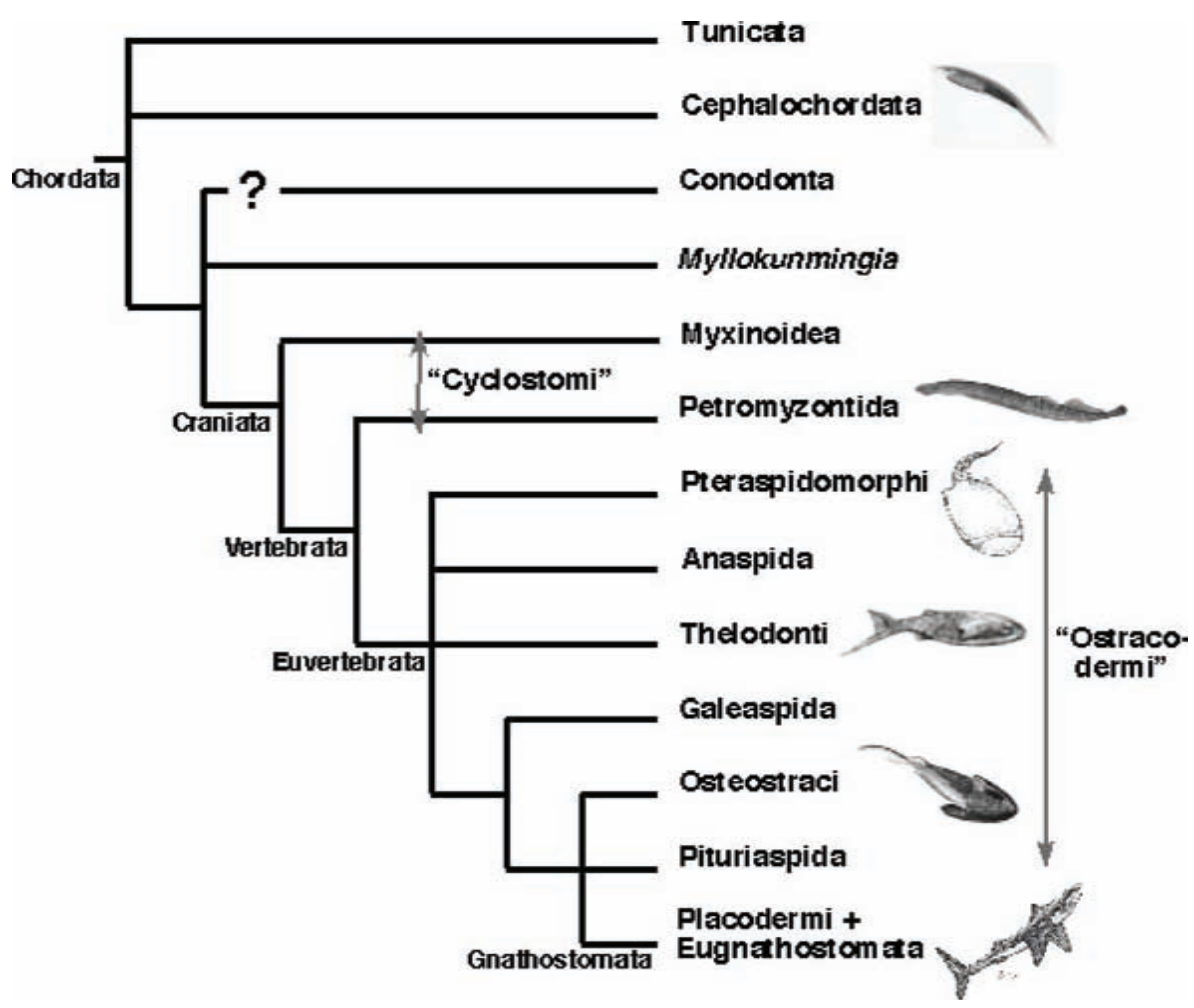

Figure 4. Schematic illustration of one of the topologies obtained in the phylogenetic (cladistic) analysis of chordates after Turner et al. (2010, modified). Some of the diagnosic features (synapomorphies) of the main taxa are as follows: Chordata- notochord; Craniata- skull; Vertebrata- arcualia (vertebrae); Euvertebrata- mineralized tissues of the skeleton (enamel or enameloid, dentine, bone); Gnathostomata-jaws; Eugnathostomata- teeth. Eugnathostomes include cartilaginous fishes (Chondrichthyes), fossil "spiny sharks" (Acanthodii), and bony fishes (Osteichthyes = Actinopterygii + Sarcopterygii). others: e.g., Long, 1995) become basal members of the TG Gnathostomata, that is, they are "jawless gnathostomes" = vertebrates with jaws without jaws $[\mathrm{sic}]$. This creates a serious problem of semantics (let alone evolution). The Total Group should be called Euvertebrata. In addition the new cladistic analysis that we ran, does not include conodonts within vertebrates nor craniates (Figure 4; Turner et al., 2010).

The third point concerns the choice of the outgroups in Donoghue et al.'s (2000) analysis (see also Donoghue and Aldridge, 2001; Sweet and Donoghue, 2001; Donoghue and Sansom, 2002; Donoghue and Purnell, 2005; Janvier, 2003, 2009; etc.) The tunicates or 'sea squirts' (also known as urochordates) and cephalochordates (amphioxus) were chosen as outgroups by them, but as both groups are already classified within the chordates, in such an analysis conodonts can only be resolved as chordates. In order to analyse the phylogenetic relationships of conodonts with chordates, the analysis should be run to include non-chordate taxa such as hemichordates (e.g. acorn worms), graptolites, echinoderms, and eventually chaetognaths (arrow worms) and priapulids (penis worms), both latter taxa having been compared to conodonts (e.g. Kasatkina and Buryi, 1996). It will immediately become obvious to all evolutionary biologists and palaeontologists that, in such a study, we will be confronted with a very difficult problem: how to define and code homologous characters of such different organisms as, for instance, graptolites and fishes, and how to code soft anatomical features which are mainly unknown for fossils (see, e.g., Janvier, 1996)? However, our analysis (Turner et al., 2010) used the same outgroups as Donoghue et al. (2000) because we based our argument upon their data matrix in order to directly compare our new results with theirs. Of course, in our analysis, conodonts are also resolved as chordates, but in a basal position, not inside the vertebrates (Figure 4).

\section{The new cladistic analysis and its results}

In order to get a result that is directly comparable with that of Donoghue et al. (2000), we followed their method, taxa and characters as closely as possible. We also used the same software for the numerical cladistic analysis, although we used the updated PAUP $4.0 \mathrm{~b} 10$ program for Windows (Swofford, 2002). We used the same 17 taxa, but only 68 characters (as compared to the 103 of Donoghue et al., 2000) because of deletion of all physiological and other characters that are based upon soft anatomical data and are not known for any fossil taxa. We also recoded some of the characters following our observations and more recently published papers (Turner et al., 2010). The result is shown in Figure 4. Some of the diagnostic features (synapomorphies) of the main taxa are as follows: Chordata are defined by the occurrence of a notochord; Craniata by a skull; 
Vertebrata by arcualia (vertebrae); Euvertebrata by mineralized tissues of the skeleton (enamel or enameloid, dentine, bone); Gnathostomata by jaws; and Eugnathostomata by teeth.

Our re-analysis supports neither a vertebrate nor a craniate relationship for conodonts. They have to be considered as basal chordates at best. However, as noted above, the choice of the two outgroups (tunicates and cephalochordates) precludes arriving at a different result. At the moment it is even uncertain whether or not conodonts are chordates, but this could only be demonstrated with a much wider analysis, which was beyond the scope of our new analysis (Turner et al., 2010). Worm-like animals with a tail, V-shaped myomeres and two anterior structures interpreted as eyes just correspond to a basic, generalized architecture for bilateral animals (see the various comparisons made with annelids, chaetognaths, priapulians, aplacophorans ...), either protostomes or deuterostomes (sensu Lecointre and Le Guyader, 2001). Additionally we doubt about the interpretation of the two big black spots as eyes with extrinsic muscles proposed for the Ordovician conodont-animal (Gabbott et al., 1995).

The new cladogram also shows, contrary to Smith et al.'s (1996) opinion, that teeth did not appear before jaws. Conodont elements are not homologous with gnathostome teeth; jaws appear within placoderms, a basal fossil group of gnathostomes, and teeth appear with eugnathostomes [although Smith and Johanson, 2003a, claim a separate appearance of teeth in some arthrodiran placoderms - see a comment by Burrow, 2003, and Young, 2003, and the reply by Smith and Johanson, 2003b], that is the "Crown Gnathostomata» of, e.g., Donoghue and Sansom (2002, fig. 3) or Donoghue and Purnell (2005, fig. 1), which includes cartilaginous fishes (Chondrichthyes), fossil "spiny sharks" (Acanthodii), and bony fishes (Osteichthyes = Actinopterygii + Sarcopterygii) (Figure 4). Our analysis also shows that the phylogenetic relationships of ostracoderms are not fully resolved, either concerning the relationships of the various ostracoderm taxa to each other, or their relationships to gnathostomes (Figure 4). This is probably the result of our data matrix, which was produced in order to analyze the conodont-vertebrate relationships, and not the ingroup relationships of euvertebrates.

\section{Conclusions}

Here, based on more detailed evidence where our histological and anatomical arguments are fully developed and used in a new phylogenetic analysis (Turner et al., 2010), we do not intend to "settle the truth", but just to try and explain that there are no valid reasons to think that conodonts are vertebrates.

With some exceptions (e.g. the unfolding 'Conodont Corner' in Turner, 1994-2000), most palaeovertebrate experts did not pay attention to the group of British conodont workers who re-opened the debate in the 1990s. This was a fundamental mistake. Because of a lack of timely and critical analysis of the assertion that conodonts are vertebrates, we now think that this erroneous idea has achieved undeserved prominence in textbooks for students and in semipopular books (e.g. Prothero, 1998; Liem et al., 2001; Benton 2005; Armstrong and Brasier, 2005), in popular scientific journals such as Scientific American (Soares, 2009), and on the Internet (e.g. Janvier, 1997, 2001). Future research should focus on a series of points:

- give a detailed description of Pikaia, a supposed Cambrian cephalochordate which was made popular by Gould (1989) but has apparently never been fully described; with its two reconstructed tentacles in Gould's book, Pikaia looks more like the enigmatic Tullimonstrum from the Pennsylvanian of Mazon Creek, Illinois, USA, or even an annelid (M. Raineri, pers. comm.);

- redescribe Yunnanozoon which has been variously interpreted as cephalochordate, chordate, craniate, hemichordate, ambulacrian, deuterostome and even bilaterian (refs in Donoghue and Purnell, 2009), and as a sclerite-bearing animal by Bergström et al. (1998);

- conduct further research on Cambrian vertebrates to discover why the only one or two possible Cambrian vertebrates known today, i.e. Myllokunmingia (Haikouichthys) and Zhongjianichthys (a possibly badly preserved myllokunmingiid) (Shu et al., 1999, 2003; Shu, 2003), have no ossified external armour (and no good vertebrate dentine) although the "Cambrian explosion" is known for the first occurrence of all kinds of biomineralisation phosphatic, siliceous, calcitic;

- and finally, re-run a phylogenetic analysis including conodonts, chordates and non-chordate organisms.

As a result, we can say what conodonts are not (vertebrates), but we cannot yet say what they are.

\section{Acknowledgements}

This paper has benefitted from fruitful discussions over the years with colleagues not least during the early vertebrate meetings held every four years since 1983 (Schultze, 2005), the yearly meetings of joint IUGS:UNESCO IGCP projects 328, 406, 491 since 1991, and other meetings on early vertebrates and Palaeozoic correlations (Gross Symposiums 1 and 2, Obruchev Symposium, Subcommission on Devonian Stratigraphy meetings, etc.). We particularly thank Dr. Anne Kemp (School of Biological Sciences, University of Queensland, St Lucia, Australia), the late Dr. David Carlisle (Canada), the late Prof. Dr. Wolf-Ernst Reif (Institut für Geowissenschaften, Eberhard-Karls Universität Tübingen, IGTU, Germany) who sadly passed away in June 2009 before completion of our paper (Turner et al., 2010), Dr. Julie Trotter (Department of Earth and Marine Sciences, Australian National University, Canberra), Prof. Dr. Otto H. Walliser (Zentrum für Geowissenschaften, Abteilung Geobiologie, Göttingen University, Germany), Dr. Rodney D. Norby (Illinois State Geological Survey, Champaign, Illinois, USA), Dr. Bruce Lieberman (University of Kansas, Department of Geology, Lawrence, Kansas, USA), Dr. Robert Nicoll (Australian Geological Survey Organisation, Canberra, Australia), and Dr. Zivile Zigaite (University of Vilnius, Lithuania). Most of the ideas developed in this paper have been presented in a series of national and international meetings: meeting of the French Palaeontological Association (APF, Lille, France, 2-5 June 2009; AB), Third International Conference Geologica Belgica (Ghent, Belgium, 14-15 Sept. 2009; AB), 69th Annual Meeting Society of Vertebrate Paleontology (SVP) and 57th Symposium on Vertebrate Palaeontology and Comparative Anatomy (SVPCA) (Bristol, UK, 23-26 Sept., 2009; AB), 79th Jahrestagung der Paläontologischen Gesellschaft (Bonn, Germany, 5-7 Oct. 2009; HPS). We also thank Prof. A. de Ricqlès (Collège de France, Paris) for his comments on a preliminary version of the paper, as well as the two reviewers Drs. Anne Kemp (University of Queensland, St Lucia, Australia) and Peter Königshof (Forschungsinstitut und Naturmuseum Senckenberg, Frankfurt am Main, Germany). 


\section{References}

Aldridge, R.J. and Briggs, D.E.G., 2009, The discovery of the conodont anatomy and its importance for understanding the early history of vertebrates, in Sepkoski, D. and Ruse, M., eds, The Paleobiological Revolution. Essays on the Growth of Modern Paleontology: University of Chicago Press, Chicago and London, pp. 73-88.

Armstrong, H.A. and Brasier, M.D., 2005, Microfossils, $2^{\text {nd }}$ edition: Blackwell, Oxford, $296 \mathrm{pp}$.

Bemis, W.E., 1987, Feeding systems of living Dipnoi: anatomy and function, in Bemis, W.E., Burggren, W.W. and Kemp, N.E., eds, The Biology and Evolution of Liungfishes (Symp. Amer. Zool., Denver, Colorado, 27 Dec. 1984): Journal of Morphology, Supplement 1 [1986], and Alan R. Liss, New York, pp. 249-275.

Benton, M.J., 2005, Vertebrate Paleontology, 3rd edition: Blackwell, Oxford, $\mathrm{XII}+474 \mathrm{p}$.

Bergström, J., Naumann, W.W., Vieweg, J. and Martí-Mus, M., 1998, Conodonts, calcichordates and the origin of vertebrates: Mitteilungen aus dem Museum für Naturkunde Berlin, Geowissenschaftliche Reihe, v. 1, pp. 81-92.

Branson, E.B. and Mehl, M.G., 1933, Conodonts Studies: University of Missouri Studies, v. 8, 349 p.

Briggs, D.E.G., Aldridge, R.J. and Smith, M.P., 1987, Conodonts are not aplacophoran molluscs: Lethaia, v. 20, pp. 381-382.

Briggs, D.E.G., Clarkson, E.N.K. and Aldridge, R.J., 1983, The conodont animal: Lethaia, v. 16, pp. 1-14.

Burrow, C.J., 2003, Comment on "Separate evolutionary origins of teeth from evidence in fossil jawed vertebrates": Science, v. 300, p. 1661b.

Donoghue, P.C.J., 1998, Growth and patterning in the conodont skeleton: Philosophical Transactions of the Royal Society of London, Series B, v. 353, pp. 633-666.

Donoghue, P.C.J. and Aldridge, R.J., 2001, Origin of a mineralized skeleton, in Ahlberg, P. E., ed., Major Events in Early Vertebrate Evolution Palaeontology, phylogeny, genetics and development. Systematics Association, Special Volume Series 61: Taylor and Francis, London and New York, pp. 85-105.

Donoghue, P.C.J. and Purnell, M.A., 2005, Genome duplication, extinction and vertebrate evolution: Trends in Ecology and Evolution, v. 20 (6), pp. 312-319.

Donoghue, P.C.J. and Purnell, M.A., 2009, Distinguishing heat from light in debate over controversial fossils: BioEssays, v. 31, pp. 178-189.

Donoghue, P.C.J. and Sansom, I.J., 2002, Origin and Early Evolution of Vertebrate Skeletonization: Microscopy Research and Technique, v. 59, pp. 352-372.

Donoghue, P.C.J., Forey, P.L. and Aldridge, R.J., 2000, Conodont affinity and chordate phylogeny: Biological Reviews, v. 75, pp. 191-251.

Gabbott, S.E., Aldridge, R.J. and Theron, J.N., 1995, A giant conodont with preserved muscle tissue from the Upper Ordovician of South Africa: Nature, v. 374 (6525), pp. 800-803.

Gould, S.J., 1989, Wonderful Life: The Burgess Shale and the Nature of History: W. W. Norton \& Co., 347 p.

Gross, W., 1954, Zur Conodonten-Frage: Senckenbergiana lethaea, v. 35 (1/ 2), pp. 73-85.

Gross, W., 1957, Über die Basis der Conodonten: Paläontologische Zeitschrift, v. 31 , pp. $78-91$.

Gross, W., 1960, Über die Basis bei den Gattungen Palmatolepis und Polygnathus (Conodontida): Paläontologische Zeitschrift, v. 34, pp. 4058.

Hass, W. H., 1941, The morphology of conodonts: Journal of Paleontology, v. 15 , pp. $71-81$.

Hass, W. H., 1962, Conodonts, in Moore, R.C., ed., Treatise on Invertebrate Paleontology, Part W: Miscellanea (by Hass, W. H., Häntzschel, W., Fisher, D. W., Howell, B. F., Rhodes F. H. T., Müller, K. J. \& Moore, R. C.): Geological Society of America and University of Kansas Press, pp. W3W69.

Janvier, P., 1988, Conodont affinity: a reply: Lethaia, v. 21 (1), p. 27.

Janvier, P., 1995, Conodonts join the club: Nature, v. 374 (6525), pp. 761762.
Janvier, P., 1996, The dawn of the vertebrates: characters versus common ascent in the rise of current vertebrate phylogenies: Palaeontology, v. 39 (2), pp. 259-287.

Janvier, P., 1997, Euconodonta, in Tree of Life. World Wide Web address: http://www.tolweb.org/Euconodonta/14832

Janvier, P., 2001, Euconodonta†, in Tree of Life. World Wide Web address: http://phylogeny.Arizona.edu/tree/eukaryotes/animals/chordata/ euconodontal

Janvier, P., 2003, Vertebrate characters and the Cambrian vertebrates, in Néraudeau, D., ed., Les chemins de l'évolution: sur les pas de Steven Jay Gould: Comptes Rendus Palevol, v. 2 (6-7), pp. 523-531.

Janvier, P., 2009, Les premiers Vertébrés et les premières étapes de l'évolution du crâne, in Coppens, Y., Padian, K., De Ricqlès, A. and Taquet, P., eds, Histoire évolutive de la vie: Comptes Rendus Palevol, v. 8 (2-3), pp. 209-219.

Jefferies, R. P. S., 1979, The origin of chordates — a methodological essay, in House, M. R., ed., The origin of major invertebrate groups. Systematics Association, Special Volume 12: Academic Press, London, pp. 443477.

Kasatkina, A.P. and Buryi, G. I., 1996, On the relation of chaetognaths and conodonts: Albertiana, v. 18, pp. 21-23.

Kemp, A., 2002a, Hyaline tissue of thermally unaltered conodont elements and the enamel of vertebrates: Alcheringa, v. 26, pp. 23-36.

Kemp, A., 2002b, Amino-acid residues in conodont elements: Journal of Paleontology, v. 76, pp. 518-528.

Kemp, A. and Nicoll, R.S., 1996, A histochemical analysis of biological residues in conodont elements, in Turner, S. and Blieck, A., eds, Gross Symposium, Volume 1: Modern Geology, v. 20 (3-4), pp. 287-302 [republished in Turner, S. and Blieck, A., eds, Gross Symposium, Volume 2: Modern Geology, Special Issue, v. 21 (1-2), pp. 197-213 with 2 colour plates (1997)].

King, C.M., Roberts, C.D., Bell, B.D., Fordyce, R.E., Nicoll, R.S., Worthy, T.H., Paulin, C.D., Hitchmough, R.A., Keyes, I.W., Baker, A.N., Stewart, A.L., Hiller, N., McDowall, R.M., Holdaway, R.N., McPhee, R.P., Schwarzhans, W.W., Tennyson, A.J.D., Rust, S. and Macadie, I., 2009, Chapter 24: Phylum Chordata - lancelets, fishes, amphibians, reptiles, birds, mammals, in Gordon, D. P., ed., New Zealand Inventory of Biodiversity, Vol. One: Kingdom Animalia: Canterbury University Press, pp. 433-553.

Lecointre, G. and Le Guyader, H., 2001, Classification phylogénétique du Vivant: Belin, Paris, 543 pp. [translated to English: The Tree of Life: A Phylogenetic Classification: Harvard University Press, Cambridge, Massachusetts, 2006]

Liem, K.F., Bemis, W.E., Walker, W.F.J. and Grande, L., 2001, Functional Anatomy of the Vertebrates: An Evolutionary Perspective, third edition: Harcourt College Publishers, Orlando, Florida, XVII +703 p.

Long, J.A., 1995, The Rise of Fishes. 500 million years of evolution: The John Hopkins University Press, Baltimore and London, 223 p.

Müller, K.J., 1981, Zoological affinities of conodonts, in Robison, R. A., ed., Treatise on Invertebrate Palaeontology, Part W: Miscellanea, Supplement 2: Conodonta: Geological Society of America and University of Kansas Press, pp. W78-W82.

Müller, K.J. and Nogami, Y., 1971, Über den Feinbau der Conodonten: Memoirs of the Faculty of Sciences Kyoto University, Series of Geology and Mineralogy, v. 38, pp. 1-88.

Pander, C.H., 1856, Monographie der fossilen Fische des silurischen Systems der russisch-baltischen Gouvernements: Kaiserliche Akademie der Wissenschaften, St. Petersburg, pp. I-X + 1-91.

Pridmore, P.A., Barwick, R.E. and Nicoll, R.S., 1997, Soft anatomy and the affinities of conodonts: Lethaia, v. 29 (4), pp. 317-328.

Prothero, D. R., 1998, Bringing Fossils to Life. An Introduction to Paleobiology: WCB McGraw-Hill, Boston, $x+457 \mathrm{p}$.

Reif, W.-E., 2006, Conodonts, odontodes, stem-groups, and the ancestry of enamel genes: Neues Jahrbuch für Geologie und Paläontologie, Abhandlungen, v. 241 (3), pp. 405-439.

Sansom, I. J., Smith, M. P., Armstrong, H. A. and Smith, M. M., 1992, Presence of the earliest vertebrate hard tissues in conodonts. Science, v. 256, pp. 1308-1311.

Sansom, R. S., Gabbott, S. E. and Purnell, M. A., 2010, Non-random decay 
of chordate characters causes bias in fossil interpretation: Nature, v. 463, pp. 798-800

Schmidt, H., 1934, Conodonten-Funde in ursprünglichem Zusammenhang: Paläontologische Zeitschrift, v. 16, pp. 76-85.

Schmidt, H., 1950, Nachträge zur Deutung der Conodonten: Decheniana, v. 104, pp. 11-19.

Schmidt, H. and Müller, K. J., 1964, Weitere Funde von Conodonten-Gruppen aus dem oberen Karbon des Sauerlandes: Paläontologische Zeitschrift, v. 38, pp. 105-135.

Schultze, H.-P., 1969, Die Faltenzähne der rhipidistiiden Crossopterygier, der Tetrapoden und der Actinoptergyier-Gattung Lepisosteus; nebst einer Beschreibung der Zahnstruktur von Onychodus (struniiformer Crossopterygier): Palaeontographia Italica, v. 65, pp. 63-137.

Schultze, H.-P., 1996, Conodont histology: an indicator of vertebrate relationship? in Turner, S. and Blieck, A., eds, Gross Symposium, Volume 2: Modern Geology, Special Issue, v. 20 (3-4), pp. 275-285.

Schultze, H.-P., 2005. The first ten Symposia on Early/Lower Vertebrates (1967-2004): Revista Brasileira de Paleontologia, v. 8 (2), pp. V-XVIII.

Scott, H.W., 1934, The zoological relationships of the conodonts: Journal of Paleontology, v. 8 (4), pp. 448-455.

Shu, D.-G., 2003, A paleontological perspective of vertebrate origin: Chinese Science Bulletin, v. 48 (8), pp. 725-735.

Shu, D.-G., Conway Morris, S., Han, J., Zhang, Z.-F., Yasui, K., Janvier, P., Chen, L., Zhang, X.-L., Liu, J.-N., Li, Y. and Liu, H.-Q., 2003, Head and backbone of the Early Cambrian vertebrate Haikouichthys: Nature, v. 421 (6922), pp. 526-529.

Shu, D.-G., Luo, H.-L., Conway Morris, S., Zhang, X.-L., Hu, S.-X., Chen, L., Han, J., Zhu, M., Li, Y. and Chen, L.-Z., 1999, Lower Cambrian vertebrates from South China: Nature, v. 402 (6757), pp. 42-46.

Smith, M.M. and Johanson, Z., 2003a, Separate evolutionary origins of teeth from evidence in fossil jawed vertebrates: Science, v. 299, pp. 12351236

Smith, M.M. and Johanson, Z., 2003b, Response to comments on "Separate evolutionary origins of teeth from evidence in fossil jawed vertebrates": Science, v. 300, p. 1661c.

Smith, M.M., Sansom, I.J. and Smith, M.P., 1996, 'Teeth' before armour: the earliest vertebrate mineralized tissues, in Turner, S. and Blieck, A., eds, Gross Symposium, Volume I: Modern Geology, Special Issue, v. 20 (3-

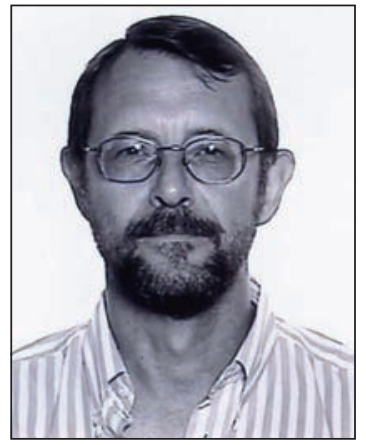

Alain Blieck is a senior research scientist at the Centre National de la Recherche Scientifique (CNRS) in Lille 1 University, France. He is a palaeontologist, biostratigrapher and palaeobiogeographer working on Early and Middle Palaeozoic vertebrates, mostly ostracoderms (agnathans) and more recently on the fish-tetrapod transition. He is a titular member of the Subcommission on Devonian Stratigraphy,

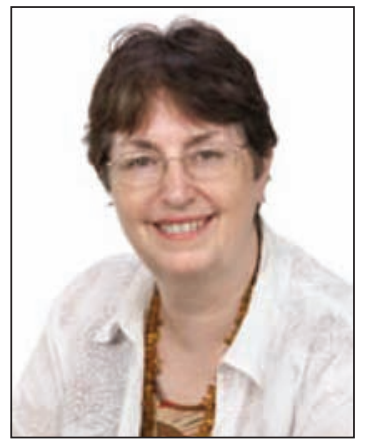

Susan Turner is a geologist and vertebrate palaeontologist who holds honorary positions at the Queensland Museum, Monash University Geosciences (Australia) and the New Brunswick Museum (Canada). She has specialised in Palaeozoic fishes and their microfossils. She has been a titular member of the Subcommission on Devonian Stratigraphy.
4), pp. 303-319.

Soares, C., 2009, Teeth - They long predate the smile: Scientific American, September 2009, p. 61.

Sweet, W.C. and Bergström, S.M., eds, 1971, Symposium on Conodont Biostratigraphy: Geological Society of America Memoir, v. 127, 499 p.

Sweet, W.C. and Cooper, B.J., 2008, C. H. Pander's introduction to conodonts, 1856: Episodes, v. 31 (4), pp. 429-432.

Sweet, W. C. and Donoghue, P. C. J., 2001, Conodonts: past, present, future, in Special $75^{\text {th }}$ Anniversary Issue, Journal of Paleontology, v. 75 (6), pp. 1174-1184.

Swofford, D., 2002, PAUP 4.0b10 for Windows: Sinauer Associates, Sunderland, Massachussets. World Wide Web address: http:// paup.csit.fsu.edu/win.html

Tillier, S. and Cuif, J.-P., 1986, L'animal-conodonte est-il un Mollusque Aplacophore? Comptes Rendus de l'Académie des Sciences, Paris, v. 303 (II), pp. 627-632.

Tillier, S. and Janvier, P., 1986, Le retour de l'animal-conodonte: La Recherche, no 183 , pp. 1574-1575.

Trotter, J. A. and Eggins, S. M., 2006, Chemical systematics of conodont apatite determined by laser ablation ICPMS: Chemical Geology, v. 233, pp. 196-216.

Trotter, J.A., Gerald, J.D.F., Kokkonen, H. and Barnes, C.R., 2007, New insights into the ultrastructure, permeability, and integrity of conodont apatite determined by transmission electron microscopy: Lethaia, v. 40 (2), pp. 97-110.

Turner, S., ed., 1994-2000, Ichthyolith Issues no. 13-21 [a newsletter for microvertebrate experts in relation to IGCP Projects 328 and 406].

Turner, S., Blieck, A. and Nowlan, G.S., 2004, Vertebrates (Agnathans and Gnathostomes), in Webby, B.D., Paris, F., Droser, M.L. and Percival, I. G., eds, The Great Ordovician Biodiversity Event: Columbia University Press, New York, pp. 327-335 + 395-466.

Turner, S., Burrow, C.J., Schultze, H.-P., Blieck, A., Reif, W.-E., Rexroad, C.B., Bultynck, P. and Nowlan, G.S., 2010, False teeth: conodontvertebrate phylogenetic relationships revisited: Geodiversitas, v. 32 (4), pp. $545-594$

Young, G.C. 2003, Did placoderm fish have teeth: Journal of Vertebrate Paleontology, v. 23, pp. 987-990

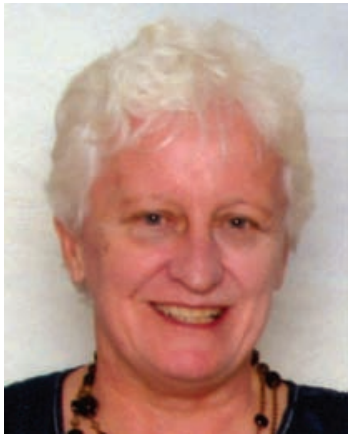

Carole J. Burrow is an honorary research fellow at the Queensland Museum in Brisbane, Australia. Her interests are the phylogenetic relationships and biostratigraphic and biogeographical distribution of mid-Palaeozoic fossil fish, in particular early jawed fishes. She is a Corresponding Member of the Subcommission on Devonian Stratigraphy.

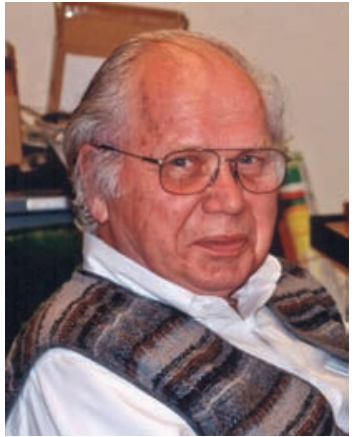

Hans-Peter Schultze, presently an emeritus, was curator at the Museum of Natural History and professor of systematics and ecology of the University of Kansas, in Lawrence, Kansas, USA. He is a specialist of early vertebrates, and in particular of sarcopterygian and actinopterygian fishes and early tetrapods, being involved in the problems of their origin and environments. 